\title{
A CONCEPTUAL FRAMEWORK OF DETERMINING THE PROPERTY VALUE USING ECONOMIC VALUATION METHOD TOWARDS FLOODS DISASTER
}

\author{
Siti Hafsah Zulkarnain \\ Centre of Studies of Estate Management \\ Faculty of Architecture, Planning and \\ Surveying \\ Universiti Teknologi MARA, 40450 \\ Shah Alam, Malaysia \\ cthafsah2u@gmail.com
}

\author{
Muhamad Ali Muhammad Yuzir \\ Malaysia-Japan International Institute of \\ Technology (MJIIT) \\ Universiti Teknologi Malaysia (UTM) \\ Kuala Lumpur, Malaysia \\ muhdaliyuzir@utm.my
}

\author{
Muhammad Najib Mohamed Razali \\ Department of Real Estate \\ Faculty of Geoinformation and Real \\ Estate \\ Universiti Teknologi Malaysia (UTM) \\ Skudai, Johor Bahru, Malaysia \\ mnajibmr@utm.my
}

\begin{abstract}
The purpose of this paper is to inform a conceptual framework of economic valuation towards floods disaster. The existing pattern, themes and issues associated with economic of valuation towards flooding were identified and used to inform the conceptual framework. The review approach was based on related literature contributing to identify themes as "floods disaster" and "property value". The generic conceptual framework presented explores the interaction between different internal and external factors affecting the economic value of properties. An extensive review of previous studies in economic valuation of property for different floods disaster studies considered to be main restrictive factor resulting in lack of empirical studies in this field. Practitioners and researchers will find this study useful in developing an improved understanding of the economic valuation to flooding. The conceptual framework is important outcome of the research which will encourage further research in this area of study.
\end{abstract}

Keywords: Conceptual framework, Floods, Economic Valuation, Property value

\section{INTRODUCTION}

Natural disaster have many different causes and include geophysical disasters such as earthquakes, tsunamis, and hydrometeorological disaster such as cyclones and floods [34]. Many disaster occur on widely different scale with different impact and little warning is given. The resulting damage takes many different forms, including death and displacement of many people, as well as damage to land, building, crops and livestock.

Flooding has been more significant in recent years due to increased urban development, with subsequent increases in water run-off and changes in world weather patterns [12]. The occurrence of such heavy rainfall and subsequent flooding has not only raised the issues of climatic change and the effect on the environment but also the more local issues of the impact on residential property development, residential property price [26] and the ability of residential property owner to gain both finance and insurance for their properties [11].

Malaysia is a country very prone to flood risk, mostly by nature of its physical as well its human geography as land use pattern of settlements. Compared to other types of disaster in Malaysia, flood are the most frequent and gives greatest damage to the properties annually.

The frequent occurrence of flooding in Peninsular Malaysia the damage caused can be significant in relation to both property damage and service disruption. Property with physically damaged requires higher operating cost of repair and maintenance which might affect directly the value of the property.

\section{PROBLEM STATEMENT}

In Malaysia, floods are caused by a combination of natural and human factors. Coupled with natural factors such as heavy monsoon rainfall, intense convection rain storms, poor drainage and other local factors, flood have become a common feature in the lives of a significant number of Malaysians [7].

During the floods generally the valuer not present and they must rely on second hand information from local residents about flood velocities and contamination content [22]. A lack of consistency in the process of assessing damage could result in varied repair methods being recommended for similarly affected properties. The valuation process in determined the current market value after disaster might be different between one and another property in same location.

The issues for the professional valuer is how to correctly identify the impact of flood and how to include these into valuation report [10]. The literature indicates the difficulties in assessing flood damages because of the lack of knowledge amongst valuer [25].

Seasonal rain began in northern and western Peninsular Malaysia starting by end of December 2016. Significantly heavy rain from 23 January 2017 have caused flooding to six (6) states in Malaysia including Kelantan, Terengganu, Perak, Pahang, Johor and Selangor. The statistic of number of evacuation of families at evacuation centres for each states are as Table 1 . 
Table 1: Evacuation families at evacuation centres as $1^{\text {st }}$ February 2017

\begin{tabular}{|c|c|c|}
\hline State & $\begin{array}{c}\text { Total number } \\
\text { of families }\end{array}$ & $\begin{array}{c}\text { Total number of } \\
\text { evacuation }\end{array}$ \\
\hline Kelantan & 21 & 105 \\
\hline Terengganu & 30 & 93 \\
\hline Perak & 181 & 576 \\
\hline Pahang & 891 & 3,210 \\
\hline Johor & 382 & 1,390 \\
\hline Selangor & 11 & 62 \\
\hline
\end{tabular}

Source: Portal Bencana, National Disaster Management Authority (NADMA, 2017)

As a results of seasonal floods occurring almost annually in one part of the country or another, flood losses in terms of loss of life and damage to properties are substantial. Damage caused during flood events can be attributed to several factors which can also affect the property value [3].

An appropriate economic valuation assessment also assists in valuing a property after disaster. The flood prone area need to take into account the risk elements while doing valuation of the property. The value of the risk is either the cost of not being affected by the disaster or the cost of bearing no loss when the disaster effectively occurs [11].

House price then reveal individual preferences [23] regarding the acceptance risk [21], assuming that appropriate control for difference in the property and the location [22] are included. There are difference between prices of houses located inside and outside a specific flood risk zone [15].

In response to these issues, the following problem statement has been developed:
"As floods and property value become more prevalent, improved valuation method practice are required for valuer and property stakeholders to determine the property value before and after disaster and developed an economic valuation model of valuation".

\section{OBJECTIVE OF RESEARCH}

The aim of this research is to develop an Economic Valuation Model using E-View Software in determining the residential property value after disaster occurs. Therefore, to achieve this aim, a list of research objectives are identified and listed as follows:

a. To determine the effects of floods on residential property value.

b. To develop Economic Valuation Model of flood impact towards property value.

c. To calibrate and validate the developed model using E-View software and integrated with GIS.

d. To estimate the property value before and after disaster within Langat River Basin.

\section{RESEARCH METHODOLOGY}

The research methodology is presented in Figure 1. The research aims and objective were achieved through a literature review, questionnaire survey, development of equation and valuation modelling and integrated flood zone map, structured interviews or focal group amongst expert area, and analysis of case study. The methodology is designed by separating this research works into four main stages as below:-

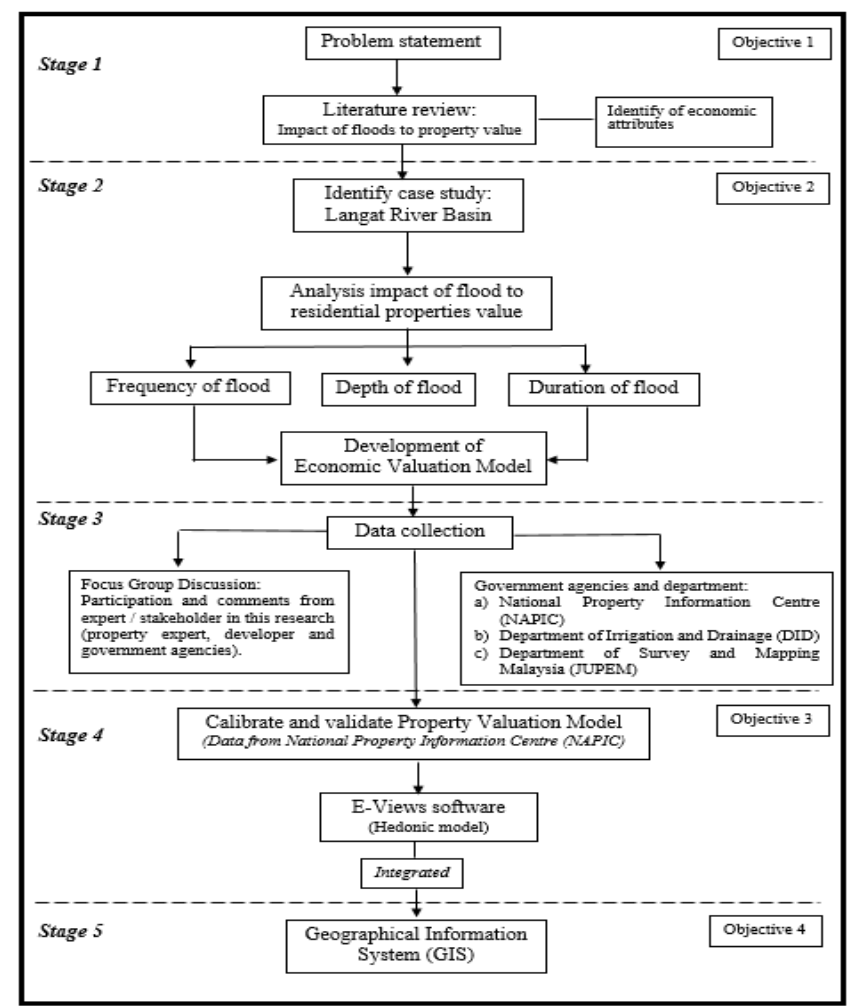

Figure 1: Research Methodology Flowchart

\section{A. Stage 1:}

At first stage, problem statement, objectives and research methodology will be determined. The research began with literature review relating to flood-risk and property, examining previous research journal and report. The literature review covered oversea and local experience and focus on flood and the impact to property value.

\section{B. Stage 2:}

The case study and model development need to be determine at this stage. Langat River Basin is chosen as case study and analysis of impact of flood in terms of frequency, duration and depth of flood as research variables.

The development of Economic Valuation Model based on literature review and assessing several previous model in determining economic property value based on various case study in valuation.

\section{Stage 3:}

At this stage, data collection in various government agencies involved in determining of property value. Data collected from National Property Information Centre (NAPIC) will be used to determine the property value before and after flood disaster event in Langat River Basin area. Besides that, the data related to flooding in terms of flood duration, depth and frequency and will be collected at Department of Irrigation and Drainage (DID). 
The expansion of Economic Valuation Model development with the participation in focus group discussion from property expert panel as a guidance in determination of the valuation factor that will give impact to property value. The key stakeholders in this research are valuer, developer, lender, property occupier, investors and related government agencies.

The survey was followed by a structured discussion with representatives of the key stakeholders groups to develop more details on the results and highlights other significant issues and identifying the suitable model.

\section{Stage 4:}

At this stage, Property Valuation Model need to be calibrate and validate. Identification of relevant variables to formulate an Economic Valuation Modelling. The formation of the Residential Valuation model for flood disaster risk is using hedonic model by E-Views software.

\section{E. Stage 5:}

In final stage, the Economic Valuation Model need to be integrated with Flood Zone Map using Geographical Information System (GIS). Latest map of the case study are based on the map provided from Department of Survey and Mapping Malaysia (JUPEM).

\section{CASE STUDY: LANGAT RIVER BASIN}

Langat River Basin is currently the fastest developing area in the country and being important water catchment area, a source of hydropower, and a source of raw water supply and another amenities [16]. The surrounding area of Langat River Basin is facing mass development in terms of urbanisation, industrialisation, highways and agriculture to more than 1.59 million people in towns such as Kajang, Bangi, Cheras and Putrajaya.

Table 2: Overview of Langat River Basin

\begin{tabular}{|c|c|c|}
\hline Overview & \multicolumn{2}{|c|}{ Description } \\
\hline Transboundary & \multicolumn{2}{|c|}{$\begin{array}{l}\text { Covers } 3 \text { states including Selangor (78\%), Negeri } \\
\text { Sembilan }(19 \%) \text { and Federal Territories of Putrajaya } \\
(3 \%) \text {. }\end{array}$} \\
\hline Location & \multicolumn{2}{|c|}{$\begin{array}{l}\text { Situated approximately } 27 \mathrm{~km} \text { to the south of Kuala } \\
\text { Lumpur (capital city of Malaysia). }\end{array}$} \\
\hline Total basin area & \multicolumn{2}{|c|}{$2,350 \mathrm{~km} . \mathrm{sq}$. and $200 \mathrm{~km}$ long } \\
\hline Topography & \multicolumn{2}{|c|}{$\begin{array}{l}\text { Approximately } 90 \% \text { mountainous with a maximum } \\
\text { height of } 1400 \mathrm{~m} \text { above sea level. }\end{array}$} \\
\hline Climate & \multicolumn{2}{|c|}{ Tropical with a mean annual temperature of $32^{\circ} \mathrm{C}$. } \\
\hline $\begin{array}{l}\text { Average annual } \\
\text { rainfall depth }\end{array}$ & \multicolumn{2}{|c|}{$\begin{array}{l}\text { Approximately } 2,400 \mathrm{~mm} \text { ranging from } 1,800 \text { to } \\
3,000 \mathrm{~mm} \text {. }\end{array}$} \\
\hline Population & \multicolumn{2}{|c|}{$1,184,917$ million in 2000, growth rate $7.64 \%$} \\
\hline $\begin{array}{l}\text { Geographical } \\
\text { location }\end{array}$ & \multicolumn{2}{|c|}{$\begin{array}{l}\text { Located ant latitude } 02^{\circ} 50^{\prime} 48^{\prime \prime} \mathrm{N} \text { and longitude } \\
101^{\circ} 40^{\prime} 48^{\prime \prime} \mathrm{E} \text {. }\end{array}$} \\
\hline \multirow[t]{8}{*}{$\begin{array}{l}\text { Main catchment } \\
\text { area }\end{array}$} & \multicolumn{2}{|c|}{$\begin{array}{l}\text { Divided into five (5) catchments comprising of the } \\
\text { Lui, Kajang, Semenyih, Dengkil and combined small } \\
\text { catchments of Beranang and Labu. }\end{array}$} \\
\hline & Catchment area & $\begin{array}{c}\text { Area } \\
\mathbf{k m}^{2}\end{array}$ \\
\hline & Lui & 70.7625 \\
\hline & Dengkil & 234.273 \\
\hline & Kajang & 310.77 \\
\hline & Semenyih & 695.548 \\
\hline & Lower Langat & 698.713 \\
\hline & Total (Langat basin) & 2012.07 \\
\hline Monsoon seasons & \multicolumn{2}{|c|}{$\begin{array}{l}\text { Two monsoon seasons in a year, the northeast } \\
\text { monsoon from November to March and southwest } \\
\text { monsoon between May and September. }\end{array}$} \\
\hline
\end{tabular}

(Sources: Billa, Assilzadeh, Mansor, Mahmud, \& Ghazali, 2011)
The event of flood can cause significant damage to the lives and properties [18] of those living within the affected area. The overview of Langat River Basin as Table 2 and Figure 2.

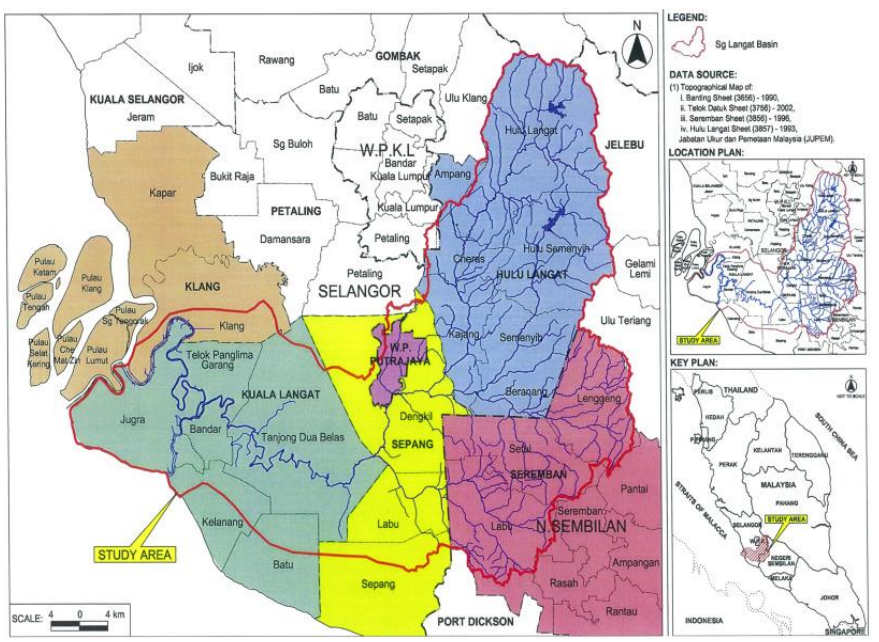

Figure 2: Langat River Basin

\section{FLOOD DISASTER INFORMATION FOR PROPERTY VALUATION}

Floods are an inevitable phenomena, their impact could be minimized by appropriate action prior to and after the flood [43]. In flood scenario, the most critical part in evaluate the flood damage assessment are rely on how to quantifying flood impact and expressing these impact in monetary values.

During the inspection and preparing the valuation report, the valuer need to have the information regarding the flood events in the early stage as Figure 3.

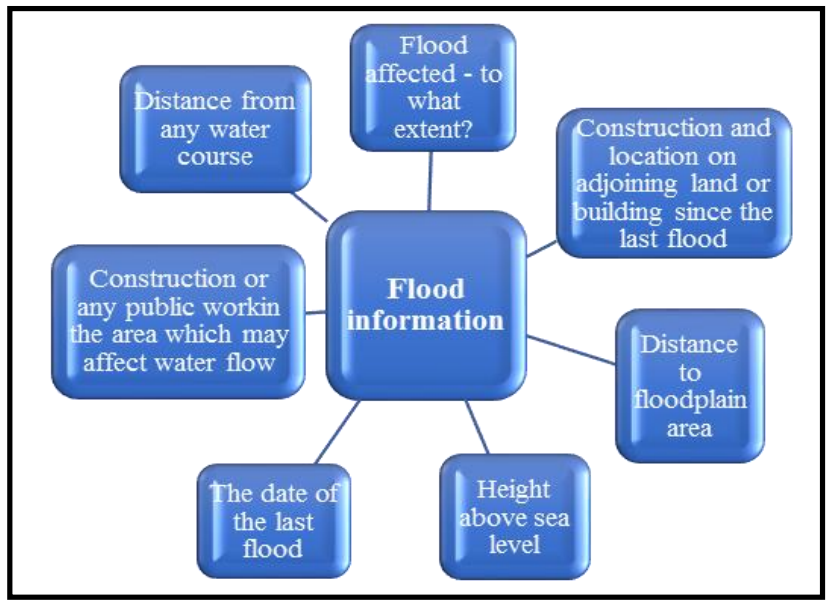

Figure 3: Flood information

Handling the valuation task related to flood is more challenging to the valuer in determining the water risks and address the potential and actual risks in the valuation report [10].

The issues rising to the professional valuer:

a. How to correctly identify potential water risk?

b. How to include the risk to valuation report? - failure to identify and address the risk in the valuation report may lead to litigation. 
Valuation reports need to be prepared by the valuer based on the instruction given from the clients. In order to derive the property value after disaster, many aspect need to be taken into account. [11] identified two (2) difficulties in the context of flood risk valuation. First, the bias subjective to individual level of perception in acceptance of risk among the property owner.

Second, the coincidence of water-related amenities and waterrelated risks. In this case, valuer need to compare house prices before and after flood events. The integration of valuation process with Geographical Information System (GIS) may improve the organization of data in terms of distance to the elevation and water front.

\section{ECONOMIC VALUATION MODEL FOR FLOOD DISASTER IMPACT ANALYSIS}

\section{A. Flood Hazard Parameter}

Impact due to urban floods are significant in terms of economic losses both direct and indirect. This is due to high density of population, large impervious areas, clogging of drainage system, high economic values of properties and infrastructures. The impact of urban floods can be physical and

The model identified the damaged caused by floods consists of two (2) key factors, that is building and flood characteristic as Table 3.

Table 3: Key factor of damaged caused by flood

\begin{tabular}{|c|c|}
\hline Key factor & Description \\
\hline $\begin{array}{l}\text { 1. Building } \\
\text { characteristic }\end{array}$ & $\begin{array}{l}\text { Include: } \\
\text { (a) Frequency of the dwelling being flooded. } \\
\text { (b) Material the building is constructed from. } \\
\text { (c) Drying characteristic of the material. } \\
\text { (d) Condition of the building prior to being } \\
\text { flooded. }\end{array}$ \\
\hline $\begin{array}{l}\text { 2. Flood } \\
\text { characteristic }\end{array}$ & $\begin{array}{l}\text { (a) Flood depth - influencing the scale of flood } \\
\text { damage. Flood depth greater then } 1 \mathrm{~m} \text { above } \\
\text { floor level may damage the building structure. } \\
\text { Velocity of floodwater - related to distance } \\
\text { from the flood source and hence the depth of } \\
\text { floodwater. The greater the floodwater } \\
\text { velocity, the greater the probability of } \\
\text { structural damage. } \\
\text { Flood water contaminants } \\
\text { i. Influence the water absorption of the } \\
\text { building material. } \\
\text { ii. Influence the drying time of material. } \\
\text { iii. Influence repair costs through the work } \\
\text { involved in the removal of physical } \\
\text { deposits. } \\
\text { iv. Embryonic form may become a danger to } \\
\text { occupier's health. } \\
\text { (d) Duration of flood - the longer the duration of } \\
\text { the flood, the more damage it will cause to the } \\
\text { building and prolonging subsequent drying } \\
\text { and repair works. } \\
\text { (e) Source of the flood - river, stream, dam, } \\
\text { sewer, which relates to the location of the } \\
\text { dwelling. }\end{array}$ \\
\hline
\end{tabular}

\section{B. Factor effecting the property value}

Residential properties is a unique product that need to meet the requirements of purchasers to own or buy a house for the purposes of investment. The complexity of the residential development nowdays, give more challenging to the developers to produce more comprehensive development of residential area with a conducive living environment and excellent amenities to the residents. Many factor involved in determining the market value of residential property instead of consideration of demand and supply as a main determination of property price.

A comprehensive summary of the literature reflect that there exist several study related to the factor affecting the residential property value focusing both at local and international scenario. Based on the previous research, the factor that effecting the property value are location [47], structural, neighborhood [42], community, environment [39], housing features [8] such as number of room, bathroom, age of property, size of land and build up area of the building.

The formation of model equation in evaluating the effect of flood on residential property value in this study are as follows:

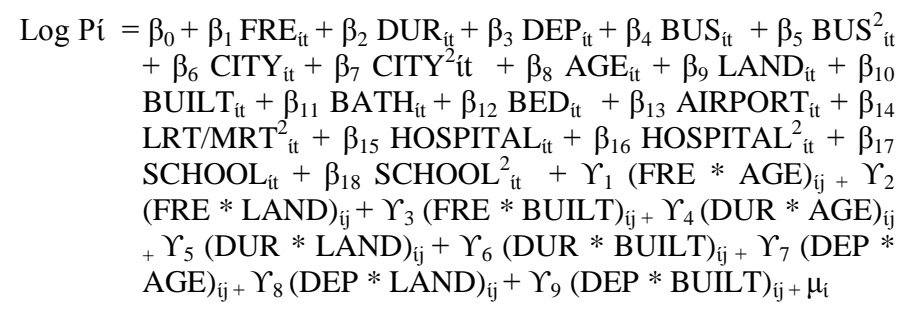

Table 4 shows the description and measurement unit of the variable for the above equation.

Table 4. Description and Measurement Units of Economic Attributes

\begin{tabular}{|c|c|c|}
\hline Variable & Description & Measurement Unit \\
\hline $\mathrm{P}$ & Price of residential property value & Ringgit Malaysia (RM) \\
\hline FRE & Frequency of flood & $\begin{array}{c}\text { Number of times within } \\
15 \text { years data }\end{array}$ \\
\hline DUR & Duration of flood & Number of days \\
\hline DEP & Depth of flood & Metres (m) \\
\hline BUS & Distance to the nearest bus station & Kilometres $(\mathrm{km})$ \\
\hline CITY & Distance to the nearest city centre & Kilometres $(\mathrm{km})$ \\
\hline AGE & Age of house & Number of years \\
\hline LAND & Size of land area & Square foot (sq. ft) \\
\hline BUILT & Size of built area (floor) & Square foot (sq. ft) \\
\hline BATH & Bathroom & Number of rooms \\
\hline BED & Bedroom & Number of rooms \\
\hline LRT / MRT & Distance to the nearest LRT / MRT & Kilometres $(\mathrm{km})$ \\
\hline HOSPITAL & Distance to the nearest hospital & Kilometres $(\mathrm{km})$ \\
\hline SCHOOL & Distance to the nearest school & Kilometres $(\mathrm{km})$ \\
\hline FRE*AGE & \multicolumn{2}{|c|}{ Relations term of flood frequency and house age } \\
\hline FRE*LAND & \multicolumn{2}{|c|}{ Relations term of flood frequency and size of land } \\
\hline FRE*BUILT & \multicolumn{2}{|c|}{ Relations term of flood frequency and size of built area (floor) } \\
\hline DUR*AGE & \multicolumn{2}{|c|}{ Relations term of flood duration and house age } \\
\hline DUR*LAND & \multicolumn{2}{|c|}{ Relations term of flood duration and size of land } \\
\hline DUR*BUILT & \multicolumn{2}{|c|}{ Relations term of flood duration and size of built area (floor) } \\
\hline DEP*AGE & \multicolumn{2}{|c|}{ Relations term of flood depth and house age } \\
\hline DEP*LAND & \multicolumn{2}{|c|}{ Relations term of flood depth and size of land } \\
\hline DEP*BUILT & \multicolumn{2}{|c|}{ Relations term of flood depth and size of built area (floor) } \\
\hline
\end{tabular}




\section{CONCLUSION}

These findings is very useful as a benchmarks to valuers and property players while carried out a valuation inspection and assessing the flood risk for residential property. The characteristic of flood events in several places is vary and critical in determining of impact of flood towards property value. The conceptual framework is important outcome of the research which will encourage further research in this area of study.

\section{Acknowledgment}

The researchers wish to express their gratitude to various parties and agencies involved in this research as follows:-
a. National Disaster Management Authority (NADMA)
b. National Property Information Centre (NAPIC)
c. Department of Irrigation and Drainage
d. Department of Survey and Mapping Malaysia (JUPEM).
e. Universiti Teknologi MARA (UiTM)
f. Universiti Teknologi Malaysia (UTM)

\section{References}

[1] Baas et al. 2008. Disaster Risk Management Systems Analysis A Guide Book.

[2] Bedate, A., Herrero, L. C., \& Sanz, J. Á. (2004). Economic valuation of the cultural heritage: Application to four case studies in Spain. Journal of Cultural Heritage, 5(1), 101-111. https://doi.org/10.1016/j.culher.2003.04.002

[3] Bhattacharya, Namrata, Jessica Lamond, David Proverbs, and Felix Hammond. 2013. "Development of Conceptual Framework for Understanding Vulnerability of Commercial Property Values towards Flooding." International Journal of Disaster Resilience in the Built Environment 4(3): 334-51. http://www.scopus.com/inward/record.url?eid=2-s2.084884194063\&partnerID=tZOtx3y1.

[4] Billa, L., Assilzadeh, H., Mansor, S., Mahmud, A. R., \& Ghazali, A. H. (2011). Comparison of recorded rainfall with quantitative precipitation forecast in a rainfall-runoff simulation for the langat River Basin, Malaysia. Central European Journal of Geosciences, 3(3), 309-317. https://doi.org/10.2478/s13533-011-0030-6

[5] Boerema, A., Schoelynck, J., Bal, K., Vrebos, D., Jacobs, S., Staes, J., $\&$ Meire, P. (2014). Economic valuation of ecosystem services, a case study for aquatic vegetation removal in the Nete catchment (Belgium). $\begin{array}{lll}\text { Ecosystem } & \text { Services, 7, 46-56. }\end{array}$ https://doi.org/10.1016/j.ecoser.2013.08.001

[6] Brémond, P., Grelot, F., \& Agenais, A.-L. (2013). Review Article: Economic evaluation of flood damage to agriculture - review and analysis of existing methods. Nat. Hazards Earth Syst. Sci., 13(10), 2493-2512. https://doi.org/10.5194/nhess-13-2493-2013

[7] Chan, Ngai Weng. 1995. "Flood Disaster Management in Malaysia: An Evaluation of Thelneffectiveness of Government Resettlement Schemes." Disaster Prevention and Management 4(4): 22-29. http://www.researchgate.net/publication/235277503.

[8] Chia, J., Harun, A., Wahid, A., Kassim, M., Martin, D., \& Kepal, N. (2016). Understanding Factors That Influence House Purchase Intention Among Consumers In Kota Kinabalu: An Application Of Buyer Behavior Model Theory. Journal of Technology Management and Business, 3(2), 94-110.'

[9] Chong Wing, C. (2016). Managing Flood Problems. Buletin Ingenieur, 38-43.

[10] Cradduck, L. (2016). After the rains: water's impact for valuation

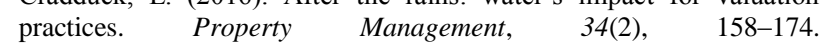
https://doi.org/10.1108/PM-11-2014-0047

[11] Daniel, V. E., Florax, R. J. G. M., \& Rietveld, P. (2009). Flooding risk and housing values: An economic assessment of environmental hazard. $\begin{array}{lll}\text { ECOLOGICAL ECONOMICS, 69(2), 355-365. } & \text {. }\end{array}$ https://doi.org/10.1016/j.ecolecon.2009.08.018

[12] Eves, Chris. 2004. "The Impact of Flooding on Residential Property Buyer Behaviour: An England and Australian Comparison of Flood Affected Property." Structural Survey 22(2): 84-94.

[13] D/iya, S. G., Gasim, M. B., Toriman, M. E., \& Abdullahi, M. G. (2014). Floods in Malaysia: Historical Reviews, Causes, Effects and Mtigations Approach. International Journal of Interdisciplinary Research and Innovations, 2(4), 59-65. https://doi.org/10.5897/AJBx10.009

[14] Harga, P., \& Klang, L. (1985). The Determinants of House Prices in the Klang Valley, Malaysia, 1, 1-19.

[15] Harrison, David M, Greg T Smersh, and Arthur L Schwartz. 2001 "Environmental Determinants of Housing Prices: The Impact of Flood Zone Status." Journal of Real Estate Research 21(1/2): 3-20. https://search-ebscohost-

com.ezp.lib.unimelb.edu.au/login. aspx ?direct $=$ true $\& d b=b$ th $\& A N=4473$ 009\&site=ehost-live.

[16] Hj Juahir, H. (2009). Water quality data analysis and data modeling of the Langat River Basin, 420. Retrieved from http://repository.um.edu.my/id/eprint/1223

[17] Islam, R., Kamaruddin, R., Ahmad, S. A., Jan, S. J., \& Anuar, A. R. (2016). A Review on Mechanism of Flood Disaster Management in Asia, 6(1), 29-52.

[18] Ismail, N. H., Karim, M. Z. A., \& Basri, B. H. (2016). Flood and land property values. Asian Social Science, 12(5), 84-93. https://doi.org/10.5539/ass.v12n5p84

[19] Jha, A. K., Bloch, R., \& Lamond, J. (2012). Cities and Flooding: A Guide to Integrated Urban Flood Risk Management for the 21st Century. https://doi.org/10.1596/978-0-8213-8866-2

[20] Jonkman, S N, M Bo, M Kok, and P Bernardini. 2007. "Integrated Hydrodynamic and Economic Modelling of Flood Damage in the Netherlands." 6.

[21] Joseph, Rotimi, David Proverbs, Jessica Lamond, and Peter Wassell. 2014. "Application of the Concept of Cost Benefits Analysis (CBA) to Property Level Flood Risk Adaptation Measures.” Structural Survey 32(2): 102-22. http://www.emeraldinsight.com/doi/10.1108/SS-122012-0043.

[22] Kenney, Sarah, Gaye Pottinger, Estate Management, and Yasmin Pocock. 2006. Flood Risk and Property Impacts on Commercial \& Residential Stakeholders 'Strategies.

[23] Koning, Koen, Tatiana Filatova, and Okmyung Bin. 2017. "Bridging the Gap Between Revealed and Stated Preferences in Flood-Prone Housing Markets." Ecological Economics 13

[24] Kropp, Sebastian. 2012. "The Influence of Flooding on the Value of Real Estate.” Journal of Building Survey, Appraisal \& Valuation: 1-11. http://henrystewart.metapress.com/index/E8093GN660X73016.pdf.

[25] Lamond, J., Proverbs, D., \& Antwi, A. (2007). The impact of flood insurance on residential property prices: Towards a new theoretical framework for the UK market. Journal of Financial Management of Property and Construction, 12(3), 129-137. https://doi.org/10.1108/13664380780001099

[26] Lamond, Jessica, David Proverbs, and Adarkwah Antwi. 2007. "Measuring the Impact of Flooding on UK House Prices." Property $\begin{array}{lll}\text { Management 25(4): 344-59. } & \text { 25 }\end{array}$ http://dx.doi.org/10.1108/02637470710775194.

[27] Lamond, Jessica, David Proverbs, and Felix Hammond. 2010. "The Impact of Flooding on the Price of Residential Property: A Transactional Analysis of the UK Market." Housing Studies 25(3): 335-56.

http://search.ebscohost.com/login.aspx?direct=true \&db=buh\&AN=500 38374\&site=ehost-live.

[28] Liew, C., \& Haron, N. A. (2013). Factors Influencing the Rise of House Price in Klang Valley. International Journal of Research in Engineering and Technology, 261-272. https://doi.org/10.1017/CBO9781107415324.004

[29] M, A., Ashikin, N., Shaari, B., Muchtar, A., Bahar, A., Adriansyah, D., ... Hayashi, T. (2014). Flood Impact Assessment in Kota Bharu, Malaysia: A Statistical Analysis. World Applied Sciences Journa, 32(4), 626-634. https://doi.org/10.5829/idosi.wasj.2014.32.04.422

[30] Mallick, H., \& Mahalik, M. K. (2014). Factors determining regional housing prices: evidence from major cities in India. Journal of Property Research,

$32(2)$,

123-146. 
https://doi.org/10.1080/09599916.2014.963642

[31] Mao, G., Onfroy, T., Moncoulon, D., Quantin, A., Robert, C., Frpshqvdwlrqv, S., ... Zlwk, D. (2016). Comprehensive flood economic losses : review of the potential damage and implementation of an agricultural impact model, 5003 https://doi.org/10.1051/e3sconf/20160705003

[32] Matsushima, K., Onishi, M., \& Kobayashi, K. (2007). Economic valuation of victims' mental damage in flood disaster. Conference Proceedings - IEEE International Conference on Systems, Man and Cybernetics, (Cvm), 1848-1853. https://doi.org/10.1109/ICSMC.2007.4413959

[33] Mariadas, P. A., Selvanathan, M., \& Hong, T. K. (2016). A Study on Housing Price in Klang Valley, Malaysia. International Business Research, 9(12), 103. https://doi.org/10.5539/ibr.v9n12p103

[34] Mitchell, David. 2010. "Land Tenure and Disaster Risk Management." Land Tenure Journal 1(10): 121-41.

[35] Mitchell, David, Helene Jacot Des Combes, Matt Myers, and Darryn Mcevoy. 2015. "Addressing Land Issues in Disaster Risk Management in the Pacific Island Countries." Land Tenure Journal 1(14): 105-35.

[36] Mitchell, David, Matt Myers, and Donald Grant. 2015. "Land Valuation A Key Tool for Disaster Risk Management." Land Tenure Journal 14(1): 37-69.

[37] Mokhtar, M. Bin, Toriman, M. E. H., Hossain, M. A. A., \& Tan, K. W. (2011). Institutional challenges for integrated river basin management in Langat River Basin, Malaysia. Water and Environment Journal, 25(4), 495-503. https://doi.org/10.1111/j.1747-6593.2010.00245.x

[38] Nijkamp, P., Vindigni, G., \& Nunes, P. A. L. D. (2008). Economic valuation of biodiversity: A comparative study. Ecological Economics, 67(2), 217-231. https://doi.org/10.1016/j.ecolecon.2008.03.003

[39] Oloke, O. C., Simon, F. R., \& Adesulu, A. F. (2013). International Journal of Economy, Management and Social Sciences An Examination of the Factors Affecting Residential Property Values in Magodo Neighbourhood, Lagos State. International Journal of Economy, Management and Social Sciences, 2(8), 639-643.

[40] Ong, T. S. (2013). Journal of Emerging Issues in Economics, Finance and Banking (JEIEFB) Factors Affecting the Price of Housing in Malaysia Journal of Emerging Issues in Economics, Finance and Banking (JEIEFB). An Online International Monthly Journal, 1(55), 2306-367.

[41] Pascal, N., Allenbach, M., Brathwaite, A., Burke, L., Le Port, G., \& Clua, E. (2016). Economic valuation of coral reef ecosystem service of coastal protection: A pragmatic approach. Ecosystem Services, 21, 72 80. https://doi.org/10.1016/j.ecoser.2016.07.005

[42] Samarasinghe, O., \& Sharp, B. (2010). Flood prone risk and amenity values: A spatial hedonic analysis. Australian Journal of Agricultural and Resource Economics, 54(4), 457-475. https://doi.org/10.1111/j.1467-8489.2009.00483.x

[43] Soetanto, R., \& Proverbs, D. G. (2006). Structural Survey Impact of flood characteristics on damage caused to UK domestic properties: the perceptions of building surveyors. Structural Survey Structural Survey Iss Structural Survey, 22(2), 95-104. https://doi.org/10.1108/02630800410538622

[44] Vo, Q. T., Kuenzer, C., Vo, Q. M., Moder, F., \& Oppelt, N. (2012). Review of valuation methods for mangrove ecosystem services. Ecological Indicators, 23, 431-446. https://doi.org/https://doi.org/10.1016/j.ecolind.2012.04.022

[45] Vranken, L., Van Turnhout, P., Van Den Eeckhaut, M., Vandekerckhove, L., \& Poesen, J. (2013). Economic valuation of landslide damage in hilly regions: A case study from Flanders, Belgium. Science of The Total Environment, 447, 323-336. https://doi.org/https://doi.org/10.1016/j.scitotenv.2013.01.025

[46] Wagemaker, J., Leenders, J., \& Huizinga, J. (2007). Economic valuation of flood damage for decision makers in the Netherlands and the Lower Mekong river basin. Water Management.

[47] Zhang, L. (2016). Flood hazards impact on neighborhood house prices: A spatial quantile regression analysis. Regional Science and Urban Economics, 60

$12-19$. https://doi.org/10.1016/j.regsciurbeco.2016.06.005 